\title{
Eugénios Voulgaris, Essai sur la tolérance (1768)
}

\section{Vassa S. Conticello}

\section{(2) OpenEdition \\ Journals}

Édition électronique

URL : http://journals.openedition.org/etudesbalkaniques/223

ISSN : 2102-5525

Éditeur

Association Pierre Belon

Édition imprimée

Date de publication : 1 janvier 1998

ISBN : 2-910860-08-6

ISSN : $1260-2116$

Référence électronique

Vassa S. Conticello, « Eugénios Voulgaris, Essai sur la tolérance (1768)», Études balkaniques [En ligne], 5 | 1998, mis en ligne le 03 décembre 2008, consulté le 21 avril 2019. URL : http:// journals.openedition.org/etudesbalkaniques/223

Ce document a été généré automatiquement le 21 avril 2019.

Tous droits réservés 


\title{
Eugénios Voulgaris, Essai sur la tolérance (1768)
}

\author{
Vassa S. Conticello
}

RÉSUMÉS

Édition critique, précédée d'une introduction, d'un essai de Voltaire paru en 1768 sur la question religieuse en Pologne.

\section{AUTEUR}

VASSA S. CONTICELLO

Centre d'étude des religions du Livre 